DOI: $10.33067 /$ SE.1.2021.3

Adam A. Ambroziak ${ }^{\star}$

\title{
Does the European Single Market Exist in the Era of a Coronavirus Pandemic? The Case of Intra and Extra-EU Trade in COVID-19-related Products
}

\begin{abstract}
The COVID-19 pandemic has been an extraordinary event for the EU Member States and a period wherein EU legislation and the efficiency of EU institutions have been put to the test. The crisis triggered by the decisions made by governments in Europe (which were motivated by their wishes to protect the health and lives of their peoples and to satisfy the rapid demand for drugs, personal protective equipment, and medical devices) disrupted market forces. Although most of these measures were based on both domestic and EU legislation, they seriously hindered the smooth functioning of the EU Single Market, including the free movement of goods. This paper aims to find out whether EU legislation succeeded in coping with the challenges triggered by COVID-19 in the field of international trade and whether measures taken by the European Commission with a view to complying with the rules of the EU Single Market adequately took care of the needs stemming from the COVID-19 outbreak and whether it properly tackled protectionist instruments adopted by the Member States. We have focused on international trade and the free movement of goods within the $\mathrm{EU}$ as they both constitute the cornerstone of EU economic integration. We found that although EU legislation was not tailored specifically for the times of a COVID-19 pandemic, in the area of international trade (including intra-EU trade), as well as in the field of placing goods on the market, it provided extraordinary solutions. Apparently, the explanations and guidelines provided by the Commission have limited the scope of individual protectionist and interventionist actions of the Member States.
\end{abstract}

Keywords: Single European Market, Physical Barriers, Border Control, Technical Barriers, COVID-19

* Adam A. Ambroziak - SGH Warsaw School of Economics, e-mail: adam.a.ambroziak@sgh.waw.pl, ORCID: 0000-0002-4618-8497. 


\section{Introduction}

It is without doubt that the COVID-19 pandemic was an extraordinary phenomenon that occurred in the spring of 2020 in the European Union. Faced with a threat to the lives and health of their peoples, practically all governments of the EU Member States decided to put restrictions and bans in place. Although most of these measures were based on both domestic and EU legislation, they seriously hindered the smooth functioning of the EU Single Market, including the free movement of goods. As a result, they have compounded the problems of businesses which, on the face of it, were protected by protectionist instruments. At the same time, the European Commission published a series of guidelines addressed at companies and public authorities in the hope of reducing the negative effects of the pandemic and, indirectly, of Member States' actions.

This paper aims to find out whether the EU legislation succeeded in coping with the challenges triggered by COVID-19 in the field of international trade and whether the measures taken by the European Commission with a view to complying with the rules of the EU Single Market adequately took care of the needs stemming from the COVID-19 outbreak and properly tackled protectionist instruments adopted by the Member States. We have focused on international trade and the free movement of goods within the EU as both constitute the cornerstone of EU economic integration. To this end, we have analysed the restrictions and barriers introduced by the Member States to tackle the COVID-19 pandemic, as well as the measures applied by the European Commission to meet the same goals ensuring, at the same time, the integrity of the single market and EU solidarity. Therefore, we have analysed restrictions on cross-border trade introduced by the EU Member States, limitations on extra-EU exports and facilitation measures in extra-EU imports applied by the European Commission as well as its liberalising approach to technical requirements on placing CE-marked goods on the EU's Internal Market. We focused our research only on COVID-19-related products: a) COVID-19 test kits (instruments and apparatus used in diagnostic testing), b) protective garments and the like, including PPE, c) disinfectants and sterilization products, d) oxygen therapy equipment, e) medical devices and equipment, f) medical consumables, and g) medical vehicles and furniture. In order to present a more comprehensive economic outlook of the consequences of the selected measures applied due to the COVID-19 pandemic, we analysed changes in intra and extra EU-27 trade in selected goods. The time frame for the research covers the first stage of COVID-19 in the EU, i.e., the period between March and September 2020. 


\section{Restrictions on Cross-border Trade}

The free movement of goods, one of the four freedoms set out in the Treaty, is the cornerstone of the European Single Market. It was implemented to legitimise the abolition of the then existing traditional barriers to trade, as well as physical (internal border controls) and technical (diverse technical requirements) barriers. ${ }^{1}$ In 2016 it was estimated that the removal of controls on one internal border is equivalent to the reduction of a tariff by 0.7 percentage points, while establishing an EU customs union and the single market is equivalent to duties of $17.82 \%$ for trade in goods. ${ }^{2}$ Thus, one needs to note that any restriction on trade increases the costs borne by companies and consumers. This was exactly the case as regards the COVID-19 outbreak when the Member States adopted restrictions on the export of specific goods from their respective territories and went on to restore border controls (those which especially affected people but which also had consequences for transported goods).

When it comes to exports (including intra-EU trade), the ban was adopted by the Member States because of major shortages not only of personal protective equipment (PPE) and medical products, but also of COVID-19 related drugs. Since all custom duties, quantitative restrictions and measures have a similar effect on customs duties and quantitative restrictions, along with the fact that physical and technical barriers to intra-EU movement of goods had been abolished as part of the free movement of goods, such measures were allowed as the so-called technical regulations introduced to serve the public interest. ${ }^{3}$ In this very case, 'technical regulation' means not only technical specifications but also solutions prohibiting the manufacture, import, and marketing of products. The Directive establishes a notification procedure to be followed before such regulations enter into force so as to be able to assess their compat-

1 A.A. Ambroziak, Handlowe skutki ewolucji prawa swobodnego przeptywu towarów. Bilans dwudziestolecia istnienia rynku wewnętrznego UE, "Studia Europejskie", no. 65(1)/2013, pp. 75-100; A.A. Ambroziak, New Challenges for the Free Movement of Goods within the Internal Market of the European Union, in: Introduction to European Studies: A New Approach to Uniting Europe, eds. D. Milczarek, A. Adamczyk, K. Zajączkowski, Center of Europe, University of Warsaw, Warsaw 2013.

2 G. Felbermayr, J. Gröschl, T. Steinwachs, Trade costs of border controls in the Schengen area, VOX EU, CEPR, 2016, https://voxeu.org/article/trade-costs-bordercontrols-schengen-area (access 31.12.2020).

3 Directive (EU) 2015/1535 of the European Parliament and the Council of 9 September 2015 laying down a procedure for the provision of information in the field of technical regulations and of rules on Information Society services (codification), OJ 2015 L 241/1, 17.09.2015. 
ibility with EU legislation. It is intended to eliminate potential barriers to trade and their negative effects already at an early stage.

The notification procedure provides for a so-called standstill clause which postpones the adoption of draft technical regulations for three months from the date of the receipt of a draft by the Commission. Within this period the Commission is expected to assess the new legal measure and, if the assessment is negative, it engages in a dialogue with the Member State concerned to eliminate potential non-compliance. During the COVID-19 outbreak in the spring of 2020, the Member States did not have a particularly long time to act which is why they decided to immediately adopt and implement new legal solutions without any consultations citing "urgent reasons occasioned by serious and unforeseeable circumstances relating to the protection of public health or safety."

Over the researched period, i.e. between March and September 2020, Member States notified several hundred technical regulations related to COVID-19 in total. However, only around a dozen of them directly concerned intra-EU trade. With regard to COVID-19-related products, new regulations provided for, among others, a ban on exports of PPE as well as drugs (Belgium, Bulgaria, Cyprus, the Czech Republic, Denmark, Estonia, France, Germany, Greece, Hungary, Latvia, the Netherlands, Poland, Romania, Slovakia, and Spain), authorising national drug agencies to oblige manufacturers, importers, and distributors to build up stocks of specific products (Denmark), selling these products in specific quantities and at specific prices to fight speculation (Denmark, the Czech Republic, France, Germany, and Slovenia), taking over products (requisitioning), carrying out supplies and distribution through appointed entities (France, Denmark, and Finland), restrictions on drug prescriptions (Estonia, Finland, and France), a reduction of VAT rates on specific PPE products (France), changes in requirements concerning the placing on the market of drugs, diagnostic products, medical devices, and PPE (France, Hungary, Italy, and Belgium), as well as restrictions on public procurement and its refocus (Sweden). ${ }^{4}$

In response to the above actions undertaken by the Member States, the European Commission already in early April 2020 adopted guidelines on drug supplies during the COVID-19 pandemic. In these guidelines the

4 TRIS Technical Regulation Information System based on the Directive (2015), https://ec.europa.eu/growth/tools-databases/tris/en/search/ (access 31.12.2020); WTO, COVID-19: Measures affecting trade in goods (as of 31.12.2020), https://www.wto. org/english/tratop_e/covid19_e/trade_related_goods_measure_e.htm?fbclid $=\mathrm{Iw}$ AR0OLsJ88V5nGjfPm4nzGi0eY8hin6sey7dUvIlHWqWJo0AbTrBziFqfb48 (access 31.12.2020). 
Commission clearly stated that total bans on the export of medicines are not compliant with the Treaty and impede the functioning of the single market. In addition, it was rightly observed that the artificial stockpiling of medicines triggers uncontrolled increases of stocks which may lead to serious shortages in places where these medicines are really needed. Notably, the Commission unambiguously highlighted that no country is self-sufficient in the raw materials, intermediates, APIs, and finished medicines required to ensure a well-functioning healthcare system. ${ }^{5} \mathrm{Obvi}$ ously, it attempted to make the governments of the Member States aware that strength lies in solidarity and not in adopting protectionist measures that, on the face of it, partly protect national interests.

Besides, in order to mitigate any negative consequences of restrictions on the free movement of people as a result of the restoration of border controls introduced by the Member States, a decision was taken to implement so-called Green Lanes (for road transport, checks at border-crossing points on the TEN-T Network were to take no more than 15 minutes) along with some facilitations in Air Cargo Operations. These solutions were intended to ensure the smooth transport of critical products such as food, medical supplies and PPE, and other products which are vital for the functioning of sensitive supply chains. The Commission argued that all vehicles in cargo transport that are used to transport, inter alia, the above-mentioned products, should be permitted to operate at all times. This was important because some Member States did not exempt cargo transport from those bans on the movement of people (it concerned special restrictions on cargo workers which de facto prevented them from carrying out normal operations. ${ }^{6}$

One should assume that the above-listed restrictive measures put in place to ensure the health and safety of citizens had some impact on the intra-EU trade of products covered by the restrictions. The value of all COVID-19related products in the first wave of the pandemic (between March and September 2020) reached EUR 134.6 bn compared to EUR 121.9 bn within a comparable period of 2019 and EUR 116.6 bn in 2018. The increase stemmed mainly from trade in medical consumables, COVID-19 test kits

5 Guidelines on the optimal and rational supply of medicines to avoid shortages during the COVID-19 outbreak, OJ 2020 C 116 I/01, 8.04.2021.

6 Communication from the Commission on the implementation of the Green Lanes under the Guidelines for border management, measures to protect health and ensure the availability of goods and essential services, OJ C 96 I/1, 24.03.2020, Guidance on customs issues related to the COVID-19 emergency https://ec.europa.eu/ taxation_customs/covid-19-taxud-response/guidance-customs-issues-related-covid19-emergency_en (access 31.12.2020). 
and, to a lesser extent, medical devices, and protective garments including PPE. In March, when COVID-19 reached Europe, the value of trade in both medicines and tests clearly increased and after restrictions were introduced by the Member States. In the following months, it returned to prepandemic levels. Thus, after an initial 2-3 months of uncertainty, despite the maintenance of restrictions which were visible in the European Single Market in particular in April, the overall size and structure of trade in individual groups of products did not change substantially compared to 2019 .

Figure 1. Intra EU-27 trade in COVID-19-related products in 2020

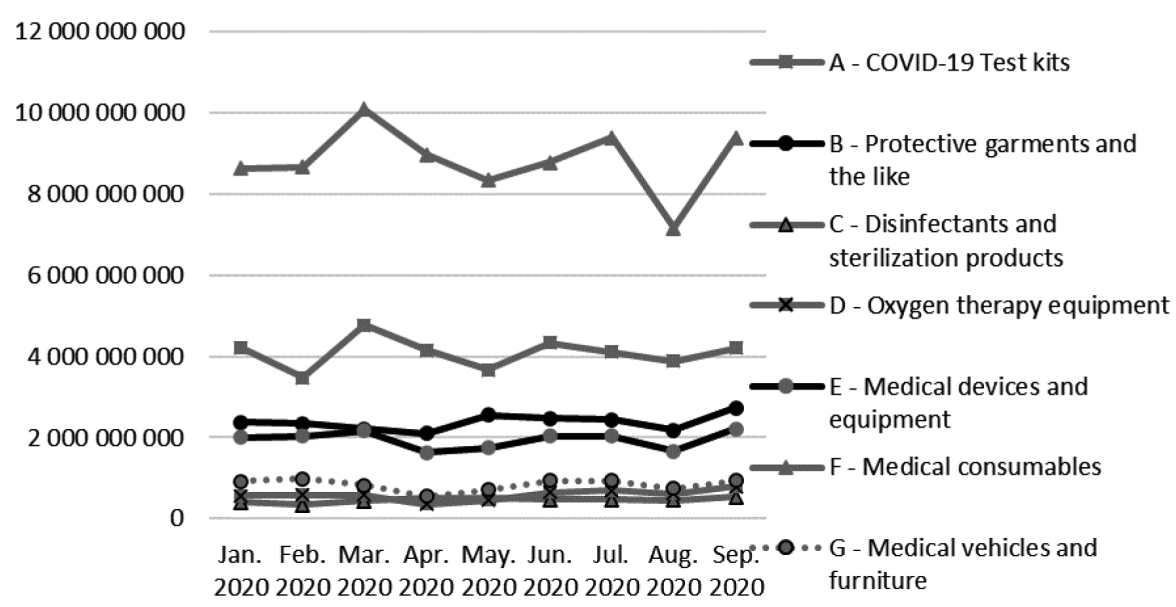

Source: Eurostat.

Sudden shortages of goods in domestic markets and a considerable increase in demand have contributed to substantial price increases. To capture the essence of this relationship, we compared the value and volume of trade in the subsequent months of 2020 compared to 2019. An indicator greater than 1 means that the relationship between the value of intra-EU exports to its volume (unit price) was greater in 2020 compared to 2019 (Table 1). The highest increase in the average unit price calculated this way was reported for COVID-19 test kits (an incredible increase of 79\% in July 2020 compared to 2019) and oxygen therapy equipment (which increased by $34 \%$ as of June). At the same time, unit prices of medical devices and equipment, not unlike protective garments including the PPE, along with disinfectants and sterilization products did not change substantially. Even though for the latter a significant increase was reported in May 2020 compared to 2019, it was compensated for with major reductions in the following months. 
Table 1. Changes in prices of COVID-19-related products in intra-EU trade in 2020 in relation to 2019

\begin{tabular}{|l|l|l|l|l|l|l|l|l|l|}
\hline Product/Period & $\begin{array}{l}\text { Jan. } \\
\mathbf{2 0 2 0}\end{array}$ & $\begin{array}{l}\text { Feb. } \\
\mathbf{2 0 2 0}\end{array}$ & $\begin{array}{l}\text { Mar. } \\
\mathbf{2 0 2 0}\end{array}$ & $\begin{array}{c}\text { Apr. } \\
\mathbf{2 0 2 0}\end{array}$ & $\begin{array}{c}\text { May. } \\
\mathbf{2 0 2 0}\end{array}$ & $\begin{array}{c}\text { Jun. } \\
\mathbf{2 0 2 0}\end{array}$ & $\begin{array}{c}\text { Jul. } \\
\mathbf{2 0 2 0}\end{array}$ & $\begin{array}{c}\text { Aug. } \\
\mathbf{2 0 2 0}\end{array}$ & $\begin{array}{l}\text { Sep. } \\
\mathbf{2 0 2 0}\end{array}$ \\
\hline $\begin{array}{l}\text { A - COVID-19 } \\
\text { Test kits }\end{array}$ & 0.71 & 1.14 & $\mathbf{1 . 3 8}$ & 1.14 & $\mathbf{1 . 4 2}$ & 1.20 & $\mathbf{1 . 7 9}$ & 1.17 & $\mathbf{1 . 4 2}$ \\
\hline $\begin{array}{l}\text { B - Protective } \\
\text { garments }\end{array}$ & 0.90 & 0.98 & 0.89 & 1.16 & $\mathbf{1 . 2 9}$ & 0.95 & 1.04 & 0.89 & 0.88 \\
\hline $\begin{array}{l}\text { C - Disinfec- } \\
\text { tants and steril- } \\
\text { ization products }\end{array}$ & 1.08 & 1.06 & 1.05 & 1.13 & 1.24 & 1.13 & 1.11 & $\mathbf{1 . 2 7}$ & 1.14 \\
\hline $\begin{array}{l}\text { D - Oxygen the- } \\
\text { rapy equipment }\end{array}$ & 0.98 & 1.02 & 1.10 & 1.14 & 1.21 & 1.34 & 1.29 & $\mathbf{1 . 2 8}$ & 1.21 \\
\hline $\begin{array}{l}\text { E- Medical de- } \\
\text { vices and equip- } \\
\text { ment }\end{array}$ & 1.20 & 1.03 & 0.80 & 0.94 & 0.93 & 0.88 & 0.96 & 0.95 & 0.93 \\
\hline $\begin{array}{l}\text { F- Medical } \\
\text { consumables }\end{array}$ & 1.08 & 1.16 & 1.25 & 1.23 & 1.07 & 0.99 & 1.11 & $\mathbf{1 . 3 4}$ & 1.03 \\
\hline $\begin{array}{l}\text { G - Medical } \\
\text { vehicles and } \\
\text { furniture }\end{array}$ & 0.97 & 1.10 & 0.98 & 0.96 & 1.05 & 0.94 & 0.91 & 0.92 & 0.94 \\
\hline
\end{tabular}

Source: The author's own calculations based on Eurostat data.

Thus, we may conclude that despite the pandemic and significant increases in demand which triggered market shortages of selected COVID-19-related products, intra-EU trade continued. Hence, restrictions introduced by the Member States, though mitigated and civilised by the EU regulations seeking to ensure the transparency of adopted measures, did not totally suspend intra-EU trade in these products. Nevertheless, they might have slightly intensified market pressure exerted by surplus demand and supply shortages on temporary price increases which were subsequently compensated - albeit gradually - by the market through increases in their production and price decreases in intra-EU trade.

\section{Restrictions on Exports Outside the EU}

On grounds of the EU's Common Commercial Policy, trade between the EU and third countries is regulated by the provisions of art. 206 and 207 of the Treaty on the Functioning of the European Union. The same provisions constitute the legal base for the Regulation of 2015 on common rules for exports. It provides for the possibility to deploy, among others, 
protective measures in exports of concrete products outside the EU to prevent a critical situation arising due to a shortage of essential products. ${ }^{7}$ It became the basis for the issuing of an implementing Regulation by the Commission in March 2020, which provides for the need to apply for authorisation for the export of selected types of PPE to competent authorities of a Member State where the exporter is established. ${ }^{8}$ Without such authorisation, exports outside the EU were prohibited. If PPE were located in a Member State other than the one where the application for export authorisation had been made, all the Member States involved should be able to make known either their consent or refusal to exports from their territories outside EU borders. Remarkably, the Commission stressed that some quantities of specific products could be exported under specific circumstances, such as ensuring aid to third countries. However, the final decision rested with a given Member State.

Despite the above discussed provisions, interested Member States and countries of the European Economic Area forced the Commission to quickly exempt Norway, Iceland, Lichtenstein, and Switzerland from the ban invoking the special relations these countries had developed within the internal market; for the Faroe Islands, Andorra, San Marino, Vatican City State, and overseas territories, the argumentation was based on their specific dependence on metropolitan supply chains of the EU Member States. ${ }^{9}$ That shows the power of the EU Single Market whose regulations are also binding in the EEA countries which, nevertheless, are treated as third countries by the EU common commercial policy. The above-mentioned provisions were initially introduced for 6 weeks and, by the end of that period, were expanded for further 30 days. Notably, acting apparently under international pressure, the Commission stressed that "it is not the intention of the Union to restrict exports any more than absolutely necessary, and the Union also wishes to uphold the principle of international solidarity in this situation of a global pandemic" and "an export authorisation system should remedy or prevent situations of shortages of essential products within the borders of the Union." Moreover, the Regulation provides for an authorisation procedure, not a total ban on justified

\footnotetext{
7 Regulation of the European Parliament and of the Council No 2015/479 of 11 March 2015 on common rules for exports, OJ L 83/34, 27.03.2015.

8 Commission Implementing Regulation 2020/402 of 14 March 2020 making the exportation of certain products subject to the production of an export authorisation, OJ L 2020 77I/1, 15.3.2020.

9 Commission Implementing Regulation 2020/426 of 19 March 2020 amending Implementing Regulation 2020/402 making the exportation of certain products subject to the production of an export authorisation, OJ $2020 \mathrm{~L} \mathrm{84I/1,20.3.2020.}$
} 
exports of the products in question. Member States should positively consider granting authorisation in cases when exports are intended for State bodies, public institutions, and bodies governed by the public law and in charge of distributing or making PPE available to persons affected by or at risk from COVID-19 or involved in combating the COVID-19 outbreak. An additional argument in favour of granting authorisation was sought in offering support to what the World Trade Organisation was doing and coordinated actions undertaken at the EU level in crisis situations unfolding in third countries. ${ }^{10}$

The new Regulation added Gibraltar and the Western Balkans to the earlier extended geographical scope of the derogation from the duty to obtain the authorisation (Albania, Bosnia and Herzegovina, Kosovo, Montenegro, Northern Macedonia, and Serbia) as candidate countries for EU membership and/or covered by special partnership arrangements; it also reminded us that the United Kingdom still had to be treated as a Member State, not as a third country.

The above solutions meant that, on the one hand, the Commission, despite pursuing the Common Commercial Policy, enabled the governments of the Member States granting individual support to non-EU countries with which they had specific political and economic links. On the other hand, it encouraged the Member States to relax trade restrictions in trade with third countries being aware of both disrupted value chains and supplies, as well as of consequences in other economic areas. Thus, it is not hard to imagine similar restrictions being put in place or straightforward bans on the exports of intermediates or raw materials necessary to produce final products in the EU. We also need to note the negative effects of a ban on trade. According to Evenett, during the crisis period, export limits raised the level and volatility of world prices while doing little to depress domestic prices which were driven, in part, by other factors. Moreover, as health professionals are on the front lines in the fight against COVID-19 and to reduce the risk to themselves of getting sick - they need protective medical kits, while export bans on masks, as PPE, erode the capability of trading partners to cope with the spread of COVID-19. ${ }^{11}$ Attention should also be paid to several consequences of any implemented restrictions: limited interest in future export production, an increased burden on Member States' budgets forced to artificially increase produc-

10 Commission Implementing Regulation 2020/568 of 23 April 2020 making the exportation of certain products subject to the production of an export authorisation, OJ L 2020 129/7, 24.4.2020.

11 S.J. Evenett, Tackling COVID-19 together. The trade policy dimension, Global Trade Alert, 2020. 
tion, a loss of trust in international trade at political and business levels, as well as the introduction of retaliatory measures by suffering countries.

One might assume that the introduced restrictions should significantly reduce the extra-EU exports of COVID-19 related products. Over a period of seven months during the first wave of the pandemic, the EU exported these products worth almost EUR 33 bn in 2020 while in the analogous period of 2019 exports amounted to EUR $28.8 \mathrm{bn}$, and in 2018 to EUR $23 \mathrm{bn}$. This increase was mostly due to the exports of products such as COVID-19 test kits, oxygen therapy equipment, as well as disinfectants, and sterilization products. On the other hand, drops (experienced mostly in April following a significant increase in March 2020) were reported in medicines, protective garments including PPE, medical devices and equipment, medical vehicles, and furniture, i.e. products directly covered by restrictions in the EU (Figure 2). The structure of extra-EU exports and trends more or less overlapped with intra-EU trade which seemed to derive from both domestic limitations and restrictions put in place at the EU level. What is noteworthy is that in many cases the problem concerned authorisation requirements, not an absolute ban on exports of specific goods which gave room for manoeuvre to State bodies and companies.

Figure 2. Extra EU-27 export of COVID-19-related products in 2020

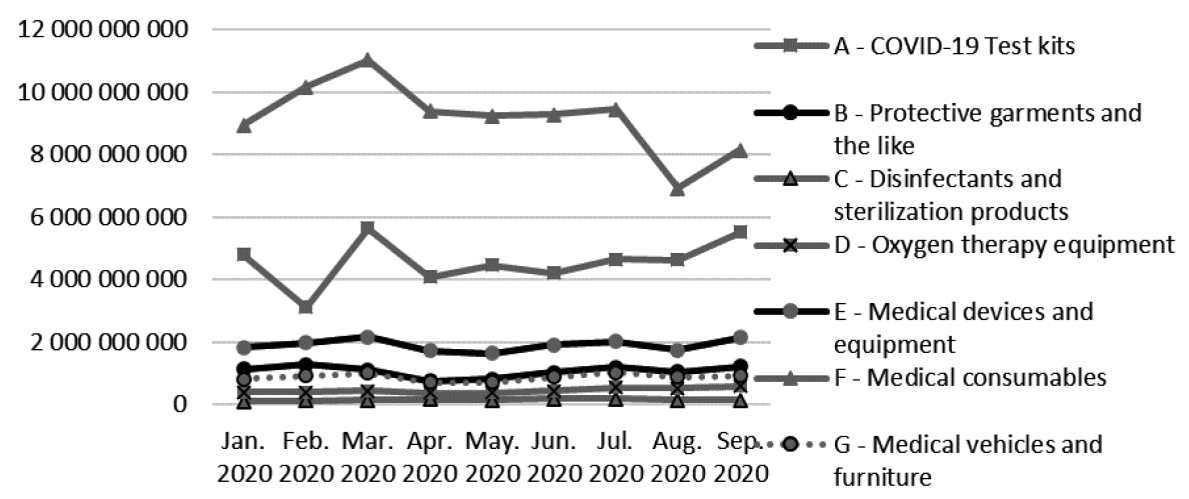

Source: Eurostat.

Given the extra-EU export value-to-volume rate in the years 20192020, we can say that, in principle, products offered by the EU were not significantly more expensive than before the pandemic. Exceptions, only in individual months, cover the COVID-19 tests and disinfectants (Table 2). Thus, it means that the imposed restrictions did not translate so 
much on price increases as in intra-EU trade. World competition and the global market, despite the pandemic, did not permit the using of inflated prices for products the supply of which, sometimes with delays, satisfied the demand.

Table 2. Changes in the prices of COVID-19-related products exported outside the EU in 2020 in relation to 2019

\begin{tabular}{|l|c|c|c|c|c|c|c|c|c|}
\hline Product/Period & $\begin{array}{l}\text { Jan. } \\
\mathbf{2 0 2 0}\end{array}$ & $\begin{array}{l}\text { Feb. } \\
\mathbf{2 0 2 0}\end{array}$ & $\begin{array}{c}\text { Mar. } \\
\mathbf{2 0 2 0}\end{array}$ & $\begin{array}{c}\text { Apr. } \\
\mathbf{2 0 2 0}\end{array}$ & $\begin{array}{c}\text { May. } \\
\mathbf{2 0 2 0}\end{array}$ & $\begin{array}{l}\text { Jun. } \\
\mathbf{2 0 2 0}\end{array}$ & $\begin{array}{c}\text { Jul. } \\
\mathbf{2 0 2 0}\end{array}$ & $\begin{array}{c}\text { Aug. } \\
\mathbf{2 0 2 0}\end{array}$ & $\begin{array}{l}\text { Sep. } \\
\mathbf{2 0 2 0}\end{array}$ \\
\hline $\begin{array}{l}\text { A - COVID-19 } \\
\text { Test kits }\end{array}$ & 0,94 & 0,76 & 1,01 & 0,67 & $\mathbf{1 , 8 3}$ & $\mathbf{1 , 3 4}$ & 1,15 & 1,08 & 1,09 \\
\hline $\begin{array}{l}\text { B - Protective } \\
\text { garments }\end{array}$ & 1,08 & 1,05 & 0,89 & 0,82 & 0,91 & 0,96 & 0,98 & 0,97 & 0,99 \\
\hline $\begin{array}{l}\text { C - Disinfec- } \\
\text { tants and steril- } \\
\text { ization products }\end{array}$ & 0,96 & 1,18 & 0,97 & 1,12 & 1,12 & $\mathbf{1 , 4 1}$ & 1,04 & $\mathbf{1 , 3 3}$ & 0,98 \\
\hline $\begin{array}{l}\text { D - Oxygen the- } \\
\text { rapy equipment }\end{array}$ & 1,01 & 0,89 & 1,21 & 1,14 & 0,97 & 1,05 & 1,24 & 1,11 & 1,13 \\
\hline $\begin{array}{l}\text { E-Medical } \\
\text { devices and } \\
\text { equipment }\end{array}$ & 0,99 & 0,83 & 0,92 & 1,14 & 0,87 & 0,94 & 0,82 & 0,89 & 0,85 \\
\hline $\begin{array}{l}\text { F- Medical } \\
\text { consumables }\end{array}$ & 1,20 & 1,19 & 1,06 & 0,86 & 0,86 & 0,92 & 0,87 & 0,79 & 0,74 \\
\hline $\begin{array}{l}\text { G - Medical } \\
\text { vehicles and } \\
\text { furniture }\end{array}$ & 0,80 & 1,07 & 1,22 & 1,11 & 1,21 & 1,06 & 0,98 & 1,09 & 1,09 \\
\hline
\end{tabular}

Source: The author's own calculations based on Eurostat data.

\section{Facilitation of Imports to the EU}

As regards imports from third countries, many EU Member States (namely Italy on 19 March 2020, France on 21 March 2020, Germany and Spain on 23 March 2020, Austria, Cyprus, the Czech Republic, Estonia, Greece, Croatia, Lithuania, the Netherlands, Poland, Portugal, and Slovenia on 24 March 2020, Belgium, Bulgaria, Denmark, Finland, Hungary, Ireland, Luxembourg, Latvia, Romania, Slovakia, and the United Kingdom on 25 March 2020, and Sweden and Malta on 26 March 2020) duly filed for exemption from customs duties and VAT on imports of some COVID-19-related products. In this case the Commission, within the framework of the Directive and a Regulation on a Community system of reliefs from customs duty (2009), lifted these duties and taxes for the period starting on 30 January and running until 31 July 2020 for prod- 
ucts intended for free-of-charge distribution to people affected or at risk from the COVID-19 pandemic or engaged in combating it provided these goods were owned by public institutions. ${ }^{12}$

The reduction of customs duties introduced by the EU was apparently important for selected groups of COVID-19-related products. For medical consumables, medical devices, and test kits, EU custom duties already amounted to $0 \%$. However, in other product groups, with a few exceptions, custom duty rates were much higher and reached $12 \%$ on, e.g., textile face masks (without a replaceable filter or mechanical parts) including surgical masks and disposable face masks made of non-woven textiles, protective garments for surgical/medical use made up of felt or nonwovens, as well as alcohol-based disinfectants.

Table 3. Tariff duties imposed on selected COVID-19-related products by the EU (1 March 2020)

\begin{tabular}{|l|c|}
\hline \multicolumn{1}{|c|}{ Categories } & Tariff \\
\hline $\begin{array}{l}\text { A - COVID-19 Test kits/ Instruments and ap- } \\
\text { paratus used in Diagnostic Test: COVID-19 Test } \\
\text { kits - Diagnostic reagents based on polymerase } \\
\text { chain reaction (PCR) nucleic acid test, diagnostic } \\
\text { reagents based on immunological reactions }\end{array}$ & $0.0 \%$ \\
\hline $\begin{array}{l}\text { B - Protective garments and the like: Face and eye } \\
\text { protection, gloves }\end{array}$ & $0-12 \%$ \\
\hline $\begin{array}{l}\text { C - Disinfectants/Sterilisation products: Alcohol } \\
\text { solutions }\end{array}$ & $\begin{array}{c}\text { Od 19.2 EUR/hl } \\
\text { do } 1.00 \mathrm{EUR} / \% \mathrm{vol} / \mathrm{hl} \\
+6.40 \mathrm{EUR} / \mathrm{hl} \\
0-6.0 \%\end{array}$ \\
$\begin{array}{l}\text { Hand sanitizer and other disinfectant preparations } \\
\text { D - Oxygen therapy equipment: Hydrogen perox- } \\
\text { ide }\end{array}$ & $0-5.5 \%$ \\
\hline $\begin{array}{l}\text { E-Medical devices: Computed tomography, scan- } \\
\text { ners, extracorporeal membrane oxygenation, medi- } \\
\text { cal ventilators, patient monitoring devices }\end{array}$ & $0.0 \%$ \\
\hline $\begin{array}{l}\text { F - Medical Consumables: Wadding, gauze, band- } \\
\text { ages, cotton sticks, syringes, with or without nee- } \\
\text { dles, tubular metal needles and needles for sutures, } \\
\text { needles, catheters, cannulae, intubation kits, paper } \\
\text { bed sheets }\end{array}$ & \\
\hline
\end{tabular}

Source: TARIC database.

${ }_{12}$ Commission, Decision 2020/491 of 3 April 2020 on relief from import duties and VAT exemption on importation granted for goods needed to combat the effects of the COVID-19 outbreak during 2020, OJ L 2020 103 I/1, 3.04.2020. 
Referring to the procedural aspects of the importation of goods, including those of a critical nature, the Commission was much more reluctant. Among some simplifications concerning empowerment for customs representation during customs procedures in e-commerce, new applications for only essential customs decisions, along with an extension of the time-limit to take decisions on applications already submitted as well as customs debts, guarantees and payments, the Commission only maintained that, based on Article 127.7 Union Customs Code Customs (UCC), it is possible to use commercial, port or transport information systems for the lodging of an entry summary declaration on condition that such systems contain the necessary particulars. Moreover, the Commission suggested, that in the case of critical goods, the UCC should offer a customs declaration lodged prior to the expected presentation of the good to customs, as well as in consecutive parts (if the shipment was split). ${ }^{13}$

The above-mentioned facilitations clearly helped in partially meeting the demand for COVID-19 related products. From March to September 2020, imports from non-EU countries amounted to EUR 98.5 bn compared to EUR 73.4 bn in 2019 and EUR 66.2 bn in 2018 . That stemmed primarily from more than a fourfold increase in April 2020 and an almost sixfold increase in May 2020 (compared to February) of imports of protective garments. Attention should be paid to the fact that custom duty rates for these products were reduced the most. For other products, the value of imports was relatively stable, save medical consumables, the value of which seriously fluctuated in the months covered by the research of the first months of coronavirus virus.

The above conditions are, to some extent, explained by an analysis of the average unit price obtained from the relationship of export value-to-volume in 2020 compared to 2019. The highest increase in the unit price interpreted in this way was revealed for the above-mentioned protective garments (the value of exports being four times higher in 2020 compared to 2019 for a volume increase of 10-20\%), disinfecting products, and oxygen therapy equipment (Table 4). It means that in the face of a substantial demand for COVID-19-related products and in the absence of any possibilities to satisfy the demand through EU production, non-EU partners took advantage of the situation and significantly

13 Regulation of the European Parliament and of the Council No 952/2013 of 9 October 2013 laying down the Union Customs Code, OJ L 2013 269/1, 10.10.2013; Guidance on customs issues related to the COVID-19 emergency (31 December 2020), https://ec.europa.eu/taxation_customs/covid-19-taxud-response/guidance-customsissues-related-covid-19-emergency_en (access 31.12.2020). 
increased prices. This trend is obviously different from the trend observed in extra-EU exports.

Figure 3. Extra EU-27 import of COVID-19-related products in 2020

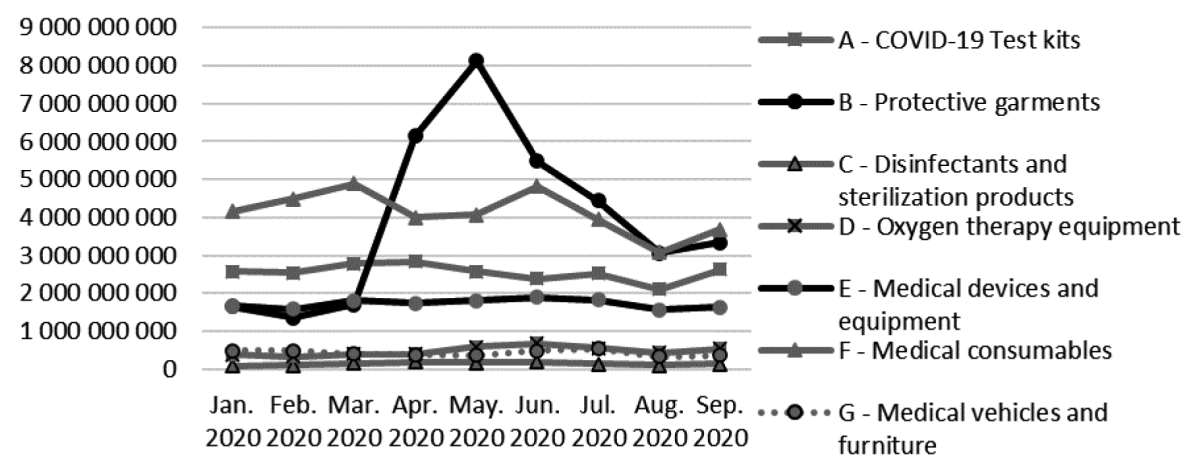

Source: Eurostat.

Table 4. Changes in price of COVID-19-related products imported to the EU in 2020 in relation to 2019

\begin{tabular}{|l|c|c|c|c|c|c|c|c|c|}
\hline \multicolumn{1}{|c|}{ Product/Period } & $\begin{array}{c}\text { Jan. } \\
2020\end{array}$ & $\begin{array}{c}\text { Feb. } \\
2020\end{array}$ & $\begin{array}{c}\text { Mar. } \\
2020\end{array}$ & $\begin{array}{c}\text { Apr. } \\
2020\end{array}$ & $\begin{array}{c}\text { May. } \\
2020\end{array}$ & $\begin{array}{c}\text { Jun. } \\
2020\end{array}$ & $\begin{array}{c}\text { Jul. } \\
2020\end{array}$ & $\begin{array}{c}\text { Aug. } \\
2020\end{array}$ & $\begin{array}{c}\text { Sep. } \\
2020\end{array}$ \\
\hline $\begin{array}{l}\text { A - COVID-19 } \\
\text { Test kits }\end{array}$ & 0,93 & 1,06 & 0,79 & 1,54 & 2,55 & 1,11 & 1,83 & 1,50 & 1,28 \\
\hline $\begin{array}{l}\text { B- Protective } \\
\text { garments }\end{array}$ & 1,02 & 0,97 & 1,15 & 4,08 & 4,53 & 2,83 & 2,20 & 1,54 & 1,33 \\
\hline $\begin{array}{l}\text { C- Disinfectants } \\
\text { and sterilization } \\
\text { products }\end{array}$ & 1,17 & 1,22 & 0,83 & 1,38 & 1,78 & 1,63 & 1,40 & 1,75 & 1,53 \\
\hline $\begin{array}{l}\text { D- Oxygen } \\
\text { therapy equipment }\end{array}$ & 0,84 & 0,84 & 0,99 & 1,44 & 2,05 & 1,92 & 1,11 & 1,12 & 1,27 \\
\hline $\begin{array}{l}\text { E-Medical } \\
\text { devices and } \\
\text { equipment }\end{array}$ & 0,93 & 0,95 & 0,97 & 1,07 & 0,91 & 0,95 & 0,90 & 0,95 & 1,01 \\
\hline $\begin{array}{l}\text { F- Medical } \\
\text { consumables }\end{array}$ & 0,90 & 0,94 & 0,65 & 1,20 & 1,27 & 0,69 & 0,79 & 0,85 & 0,57 \\
\hline $\begin{array}{l}\text { G - Medical } \\
\text { vehicles and } \\
\text { furniture }\end{array}$ & 1,04 & 1,02 & 0,75 & 0,96 & 1,03 & 0,85 & 1,00 & 0,79 & 0,88 \\
\hline
\end{tabular}

Source: own calculation based on Eurostat data. 


\section{Technical Entry Requirements}

Due to the COVID-19 outbreak, there was a massive redesigning of supply chains and a shifting in the manufacturing of economic entities towards the production of in demand COVID-19 related products, especially PPE. To this end, many companies decided to redesign their supply chains by launching new manufacturing lines or diversifying their supplier base. Placing PPE and medical devices in the EU Single Market is strictly regulated and scrutinised on the basis of technical harmonisation. ${ }^{14}$ On the one hand, these provisions were seeking to ensure user safety but, for obvious reasons, implied not only an additional financial burden but, above all, triggered conformity assessment procedures involving notified bodies competent for new types of $\mathrm{PPE}^{15}$, which significantly delayed their being placed on the market. ${ }^{16}$

14 Council Directive 89/686/EEC of 21 December 1989 on the approximation of the law of the Member states relating to personal protective equipment, OJ L 1989 399/18, 30.12.1989; Regulation of the European Parliament and of the Council No 2016/425 of 9 March 2016 on personal protective equipment and repealing Council Directive 89/686/EEC, OJ L 85/51, 30.12.1989, and 1993 Directive 93/42/EEC of 14 June 1993 concerning medical devices, OJ 1993 L 169/1 12.07.1993; Regulation of the European Parliament and of the Council No 2017/745 of 5 April 2017 on medical devices, amending Directive 2001/83/EC, Regulation (EC) No 178/2002 and Regulation (EC) No 1223/2009 and repealing Council Directives 90/385/EEC and 93/42/ EEC, OJ L 2017 117/1, 5.05.2017 respectively).

15 Not all medical devices and PPE require the intervention of notified bodies. Firstly, the procedure covers class III, IIa, and IIb devices, as in the case of respiratory patient ventilators, as well as for class I devices supplied in sterile condition. As regards class I devices (medical face masks, gloves and overalls when supplied in non-sterile condition), manufacturers are obliged to perform a conformity assessment themselves (also with the support of external laboratories) under their sole responsibility. When it comes to the PPE, the notified bodies must be engaged in a conformity assessment for categories II and III of equipment (respiratory protection face masks used in the COVID-19: FFP2 or FFP3 masks) before it is placed on the European Single Market.

${ }_{16}$ The PPE Regulation stresses that the manufacturer is obliged to perform a conformity assessment procedure. The requirement is also addressed to manufacturers from outside the EU, meaning the importers must ensure that the PPE placed by them on the market complies with the requirements set out in the Regulation of 2016 and that there is technical documentation available for surveillance purposes. According to data from the Polish notified body - Centralny Instytut Ochrony Pracy [Central Institute for Labour Protection], in order to carry out all the tests for the assessment of conformity with an adequate European harmonised standard for one type of filtering half masks, they need 50 such half masks and the standard deadline for tests is 25 days with the latter being shortened to 14 days when sample preparation and conditioning procedures are justifiably simplified. The net cost of testing has 
To enable a quick increase in the supply of selected COVID-19-related products while maintaining high levels of safety, the European Commission issued a special recommendation on 13 March $2020,{ }^{17}$ which introduced some simplicities in placing selected PPE (such as face masks, gloves, protective coveralls or eye-wear protection, as well as for medical devices such as surgical masks, exploration gloves and some gowns) and medical devices essential for healthcare workers in the European Single Market. Obviously, the Recommendation has no binding effect, but it identifies several areas in which the conformity procedure could be simplified. First of all, the Commission stressed that the notified bodies should prioritise a conformity assessment of PPE which seems an obvious requirement. However, we need to bear in mind that these bodies are commercial operators and neither the Commission nor national authorities could impact their activities.

Manufacturing processes which rely on solutions which were provided by harmonised standards guaranteed that a product would be presumed to be in conformity with the essential requirements of the Directive and currently the Regulation on PPE and medical devices (an entity placing a product on the market is obliged to observe the minimum technical requirements laid down in the regulations which specify only the potential risks to ensure user safety without defining its components or production modes). In its recommendation, the Commission extended the presumption of conformity to other technical solutions that are not harmonised European standards so as to include recommendations from the World Health Organisation. In the Commission's view, such technical solutions may be used as a source of reference, provided that they ensure the level of protection corresponding to that which is guaranteed by EU legislation. This approach made it possible to place on the market the PPE products not originally intended for the EU market which, if manufactured in accordance with WHO recommendations, could be marketed within the EU. In this case, all notified bodies were obliged to immediately notify both the national notifying authority and other notified bodies of the certificates issued.

been estimated at EUR 3,300. For masks with replaceable filters the time of testing is shortened to 7 days while for medical face masks it is extended to 30 days at a cost of EUR 2,300 (CIOP, Komunikat nr 1 w sprawie badania i oceny zgodności środków ochrony dróg oddechowych, odzieży ochronnej oraz środków ochrony oczu i twarzy w kontekście działań prewencyjnych związanych z pandemią COVID-19, 19 marca 2020, update 9 września 2020).

17 Commission Recommendation No 2020/403 of 13 March 2020 on conformity assessment and market surveillance procedures within the context of the COVID-19 threat, OJ L $202079 \mathrm{I} / 1,16.03 .2020$. 
This was a breakthrough in the practice of technical harmonisation to date. Therefore, the Commission indicated in its recommendation that the relevant market surveillance authorities in the Member States should, as a matter of priority, focus on PPE and medical devices that could pose a serious risk to the health and safety of their intended users.

At the same time, the Commission enabled market surveillance authorities in the Member States to use their superior position by allowing them to authorise the making available of PPE and medical devices on the EU market for a limited period of time along with where certain conformity procedures laid down in the relevant legislation, including the affixing of the CE marking, have not been completed. This meant that where traders, in cooperation with notified bodies, have not carried out the prescribed conformity assessment procedures, national market surveillance authorities, through their laboratories, could do so. This also applied to the placing on the market of PPE and medical devices purchased by the governments of Member States directly by government agencies or State-owned enterprises. In the latter case, the Commission allowed PPE products to be purchased without a CE marking by the competent authorities of the Member States, but only for healthcare professionals for the duration of the COVID-19 crisis.

The above meant that PPE products fully non-compliant with the essential requirements of the relevant EU directives and regulations could be imported into the EU. The lack of any enforcement of such requirements (even temporarily and for a specific group of end-users) illustrates the dramatic situation on the EU market and the insufficient supply of PPE as a basic solution to limit the spread of COVID-19. Of note, the Regulation of 2017 provided for a derogation from the conformity assessment procedure for medical devices. It was motivated by public health, patient safety or health-based premises; those which were clearly fulfilled by the COVID-19 pandemic. Under such circumstances, the Commission could, through the implementing acts, extend for a limited period of time the validity of an authorisation granted by a Member State to the territory of the Union and set the conditions under which the device may be placed on the market or put into service. Thus, one might say that although the Commission has made the system of placing goods on the market slightly more flexible, especially with regard to PPE, it nevertheless did not go beyond the restrictive framework of technical harmonisation rules and certain facilitations were copied after solutions had been previously adopted for similar (medical) products. 


\section{Conclusions}

The COVID-19 pandemic has been an extraordinary event for the EU Member States and a period when EU legislation and the efficiency of EU institutions have been put to the test. The crisis triggered by the decisions made by governments in Europe as well as in other parts of the world (motivated by the wish to protect the health and lives of their peoples and to satisfy the rapid demand for drugs, personal protective equipment, and medical devices) disrupted market forces. The lack of balance between supply and demand was, to some extent, deepened by the chaotic actions of decision-makers who, instead of looking for common solutions to problems, decided to go down a protectionist and interventionist path.

This paper aimed to find out whether the EU legislation in the area of international trade has lived up to the challenges of COVID-19 and whether actions undertaken by the European Commission to comply with EU Internal Market rules provided an adequate response to the needs stemming from the COVID-19 outbreak, as well as protectionist instruments applied by the Member States. Initial analyses let us believe that, despite some awkwardness exhibited in the first weeks of pandemic in Europe, within the EU Internal Market the European Commission rose to the challenge and focused Member States' actions on activities that least undermined its principles while Union legislation turned out to be sufficiently flexible.

When it comes to intra-EU trade, the cornerstone of integration, for COVID-19 related products it was possible to maintain trade activities at a level close to the pre-pandemic period. At the outset of the pandemic, many Member States put restrictions on exports of selected products including PPE, medical devices, and medical consumables. However, the EU system that obliges the notification of such restrictions to the European Commission, even though it was not built with such situations in mind, ensured full transparency of actions. Due to that, the introduced restrictions were known to other partners within the EU Single Market and the calculated average unit prices did not increase significantly.

The situation was slightly different when it comes to extra EU-27 trade. For exports, it can be considered that, apart from some fluctuations for some products, their position has not been affected, despite a restriction introduced at the EU level. This restriction, however, resulted in the need to apply for an authorisation for exports of selected COVID-19 -related products and was not a total ban. As a result, it was left to both entrepreneurs and public authorities of the Member States to decide on the distribution of products under special regulations. As far as imports 
are concerned, however, they increased dramatically as regards protective garments, including PPE and products commonly sought after in April and May when European production failed to keep pace with a sudden increase in demand. The answer to this was, primarily, imports from China. However, partners from outside the EU definitely took advantage of the shortage of some products, satisfying demand with much more expensive ones. In the face of this, it took two months for imports to return to prepandemic levels.

Attention should also be paid to what the European Commission was doing within the realm of the EU Single Market. Firstly, facilitations implemented with regard to meeting technical requirements and placing goods on the market (PPE and medical devices) were not substantially amended but just presented in a more transparent manner to potential manufacturers (which ensured rapid shifts in the production profiles of many European firms) or reasonably adjusted to suit needs (seeing WHO recommendations as corresponding to the technical specifications of the EU harmonised standards guaranteeing the safety of products).

In summary, it can be concluded that although EU legislation was not tailored specifically for the times of the COVID-19 pandemic, in the area of international trade (including intra-EU trade) as well as in the field of placing goods on the market, it came up with extraordinary solutions. Apparently, the explanations and guidelines provided by the Commission have limited the scope of individual protectionist and interventionist actions of the Member States. Such actions might have ensured self-sufficiency in the supply of one of the desired products (e.g., PPE), but they would not have guaranteed access to other products, including, e.g., a vaccine produced by another country which could, on a reciprocal basis, turn its back on the potential needy. This aspect is rarely considered in political decisions which have a significant economic and social impact.

\section{References}

Ambroziak A.A., Handlowe skutki ewolucji prawa swobodnego przeptywu towarów. Bilans dwudziestolecia istnienia rynku wewnętrznego UE, "Studia Europejskie", no. 65(1)/2013, pp. 75-100.

Ambroziak A.A., New Challenges for the Free Movement of Goods within the Internal Market of the European Union, in: Introduction to European Studies: A New Approach to Uniting Europe, eds. D. Milczarek, A. Adamczyk, K. Zajączkowski, Center of Europe, University of Warsaw, Warsaw 2013. 
Ambroziak A.A., New Industrial Policy of the European Union, Springer, Switzerland 2017, DOI: https://doi.org/10.1007/978-3-319-39070-3.

CIOP, Komunikat nr $1 \mathrm{w}$ sprawie badania i oceny zgodności środków ochrony dróg oddechowych, odzieży ochronnej oraz środków ochrony oczu i twarzy w kontekście działań prewencyjnych związanych z pandemią COVID-19, 19 marca 2020, update 9 września 2020.

Commission Implementing Regulation 2020/402 of 14 March 2020 making the exportation of certain products subject to the production of an export authorisation, OJ $2020 \mathrm{~L} 77 \mathrm{I} / 1,15.3 .2020$.

Commission Decision 2020/491 of 3 April 2020 on relief from import duties and VAT exemption on importation granted for goods needed to combat the effects of the COVID-19 outbreak during 2020, OJ $2020 \mathrm{~L}$ $103 \mathrm{I} / 1,3.04 .2020$.

Commission Implementing Regulation 2020/426 of 19 March 2020 amending Implementing Regulation 2020/402 making the exportation of certain products subject to the production of an export authorisation,OJ $2020 \mathrm{~L} 84 \mathrm{I} / 1,20.3 .2020$.

Commission Implementing Regulation 2020/568 of 23 April 2020 making the exportation of certain products subject to the production of an export authorisation, OJ 2020 L 129/7, 24.4.2020.

Commission Recommendation No 2020/403 of 13 March 2020 on conformity assessment and market surveillance procedures within the context of the COVID-19 threat, OJ 2020 L 79 I/1, 16.03.2020.

Communication from the Commission on the implementation of the Green Lanes under the Guidelines for border management, measures to protect health and ensure the availability of goods and essential services OJ C $96 \mathrm{I} / 1,24.03 .2020$.

Council Directive 89/686/EEC of 21 December 1989 on the approximation of the law of the Member states relating to personal protective equipment, OJ 1989 L 399/18 30.12.1989.

Council Directive 89/686/EEC of 14 June 1993 concerning medical devices, OJ 1993 L 169/1 12.07.1993.

Directive (EU) 2015/1535 of the European Parliament and the Council of 9 September 2015 laying down a procedure for the provision of information in the field of technical regulations and of rules on Information Society services (codification), OJ L 2015 241/1, 17.09.2015.

Evenett S.J., Tackling COVID-19 together. The trade policy dimension, Global Trade Alert, 2020.

Felbermayr G., Gröschl J., Steinwachs T., Trade costs of border controls in the Schengen area. VOX EU, CEPR, 2016, https://voxeu.org/article/tradecosts-border-controls-schengen-area (access 31.12.2020). 
Guidance on customs issues related to the COVID-19 emergency (https:// ec.europa.eu/taxation_customs/covid-19-taxud-response/guidancecustoms-issues-related-covid-19-emergency_en (access 31.12.2020).

Guidelines on the optimal and rational supply of medicines to avoid shortages during the COVID-19 outbreak, OJ C $2020116 \mathrm{I} / 01$, 8.04.2020.

Regulation of the European Parliament and of the Council No 952/2013 of 9 October 2013 laying down the Union Customs Code, OJ $2013 \mathrm{~L}$ 269/1, 10.10.2013.

Regulation of the European Parliament and of the Council No 2017/745 of 5 April 2017 on medical devices, amending Directive 2001/83/EC, Regulation (EC) No 178/2002 and Regulation (EC) No 1223/2009 and repealing Council Directives 90/385/EEC and 93/42/EEC, OJ L 117/1.

Regulation of the European Parliament and of the Council No 2015/479 of 11 March 2015 on common rules for exports, OJ 2015 L 83/34, 27.3.2015.

Regulation of the European Parliament and of the Council No 2016/425 of 9 March 2016 on personal protective equipment and repealing Council Directive 89/686/EEC, OJ 2016 L 85/51, 31.03.2016.

TRIS Technical Regulation Information System based on the Directive (2015), https://ec.europa.eu/growth/tools-databases/tris/en/search/ (access 31.12.2020).

WTO (2020) COVID-19: Measures affecting trade in goods (as of 18 November 2020), https://www.wto.org/english/tratop_e/covid19_e/trade related_goods_measure_e.htm? fbclid=IwAR0OLsJ88V5nGjfPm4nz Gi0eY8hin6sey7dUvIlHWqWJo0AbTrBziFqfb48 (access 31.12.2020). 